\title{
Effect of the deficiency of nitrate and silicate on the growth and composition of the benthic diatom Navicula incerta
}

\author{
José Jesús Encinas-Arzate ${ }^{1}$, Enrique Marquez-Ríos ${ }^{2}$, José Antonio López-Elías² \\ Wilfrido Torres-Areola ${ }^{1}$, José Ángel Huerta-Ocampo ${ }^{3}$ \& Juan Carlos Ramírez-Suárez ${ }^{3}$ \\ ${ }^{1}$ Departamento de Investigación y Posgrado en Alimentos \\ Universidad de Sonora, Hermosillo, Sonora, México \\ ${ }^{2}$ Departamento de Investigaciones Científicas y Tecnológicas \\ Universidad de Sonora, Hermosillo, Sonora, México \\ ${ }^{3}$ Centro de Investigación en Alimentos y Desarrollo, Hermosillo, Sonora, México \\ Corresponding author. José Antonio López-Elías (jalopez@guayacan.uson.mx)
}

\begin{abstract}
Navicula incerta is a benthic diatom with potential use in nutrition and health for humans and aquaculture. Therefore, it is important to know its optimal growth conditions and biochemical composition. In this study, the effects of nitrate and silicate concentration on the growth kinetics and biochemical composition of $N$. incerta under laboratory conditions were measured. F/2 media was used as the control, and different concentrations of nitrogen (N/4, N/8 and N/16) and silicates (Si/4, Si/8 and Si/16) were evaluated. We measured cell concentration, chlorophyll- $a$ and conducted proximal chemical analyses. It was found that different concentrations of nutrients affected the diatom's growth kinetics and affected the concentrations of ash, chlorophyll, protein, lipids and carbohydrates. The highest concentration of lipids was obtained in the limiting treatment of nitrogen N/8 (27.09\%), while the lowest value was found with silicate Si/8 media (16.97\%). Carbohydrates increased compared to the control, with the N/16 treatment presenting the maximal concentration $(23.31 \%)$. Treatments with reduced nitrate (N/8 and N/16) demonstrated the lowest concentrations of protein (18.75 and $12.44 \%$, respectively), while in reduced silicate treatments, no statistical differences $(P \geq 0.05)$ were observed. Therefore, media limited nitrogen and silicates affected the growth kinetics and proximal chemical composition of $N$. incerta. The growth of this species using the N/8 medium is a suitable method for increasing lipid concentration in $N$. incerta.
\end{abstract}

Keywords: Navicula incerta; stress response; growth; lipid production; proximal composition; nutrient limiting; chlorophyll

\section{INTRODUCTION}

Several authors have reported that one of the limiting factors in obtaining and producing food is the nutritional requirements associated with its growth (Parashuramulu et al., 2013; Méndez-Martínez et al., 2018). For years, microalgae have been used for feeding animals and humans (García-González et al., 2005). They are highly efficient in producing a wide variety of chemical components, such as fatty acids, pigments and other biologically active compounds of interest (Rema \& Gouveia, 2005; Yaşar \& Şevket, 2006; Mooij et al., 2016). The genus Navicula is a benthic diatom that presents great potential for the production of these compounds (Leal et al., 2013; Fimbres-Olivarría et al., 2015). Also, they are already used for their high production of fatty acids for aquaculture and human consumption. Generally, microalgae have been predicted to be an essential supply feedstock for food, fuels and chemicals in a biobased economy (Wijffels \& Barbosa, 2010; Mooij et $a l ., 2016)$. For these reasons, it is important to seek the best growth conditions to produce these compounds.

It has been reported that the concentration of nutrients in the culture medium affects microalgal metabolism and the production of bioactive compounds

Corresponding editor: José Luis Iriarte 
(Spolaore et al., 2006; Kang et al., 2011; Jiang et al., 2015). The concentration of nitrates, and especially of silicates, in diatoms is essential for the biosynthesis of compounds such as lipids and carbohydrates (Vitova $e t$ al., 2015; Lari et al., 2016). Some authors have reported nitrogen limitation as to the most efficient strategy to increase the content of neutral lipids in microalgae, mainly triglycerides, which are constituted of highly saturated fatty acids (Pal et al., 2011; Huang et al., 2013). On the other hand, silicate content is important for the biosynthesis of the diatom cell wall, and it is fundamental for the regulation of cell division and the accumulation of certain compounds such as lipids (Pérez-García et al., 2011).

Several studies have been conducted to study the main factors affecting the production of biomass, as well as the bioactive compounds produced by Navicula incerta (Tzovenis et al., 2003; Kang et al., 2011; Jiang et al., 2015). However, the effect of silicate and nitrogen concentration in the culture medium has not been investigated. Therefore, the purpose of this research was to evaluate the effect of these nutrients on the growth kinetics, chlorophyll, biomass, lipid, protein, and carbohydrate contents of $N$. incerta.

\section{MATERIALS AND METHODS}

\section{Algal strain and culture conditions}

The microalgae Navicula incerta was obtained from the Centro de Investigación Científica y de Educación Superior de Ensenada (CICESE), Baja California State, Mexico. As a control, a culture of microalgae in a $1 \mathrm{~L}$ Erlenmeyer flask, under standard conditions $\left(25^{\circ} \mathrm{C}, 35\right.$ of salinity and controlled light $260 \mu \mathrm{mol}$ photon $\mathrm{m}^{2} \mathrm{~s}^{-1}$ for $24 \mathrm{~h}$ ), containing $700 \mathrm{~mL}$ Guillard \& Ryther medium (F/2) (Guillard \& Ryther, 1962; Renaud et al., 1994 ) with $0.88 \mathrm{~mol} \mathrm{~L}^{-1}$ of nitrogen and $0.32 \mathrm{~mol} \mathrm{~L}^{-1}$ of silicate. For each treatment, $700 \mathrm{~mL}$ of medium with different nitrate (N/4: $0.44 \mathrm{~mol} \mathrm{~L}^{-1}, \mathrm{~N} / 8: 0.22 \mathrm{~mol} \mathrm{~L}^{-1}$ and N/16: $0.11 \mathrm{~mol} \mathrm{~L}^{-1}$ of $\mathrm{NaNO}_{3}$ in Guillard $\mathrm{F} / 2$ medium) and silicate (Si/4: $0.16 \mathrm{~mol} \mathrm{~L}^{-1}, \mathrm{Si} / 8: 0.08 \mathrm{~mol}$ $\mathrm{L}^{-1}$ and $\mathrm{Si} / 16$ : $0.04 \mathrm{~mol} \mathrm{~L}^{-1}$ of $\mathrm{Na}_{2} \mathrm{SiO}_{3} .9 \mathrm{H}_{2} \mathrm{O}$ in $\mathrm{F} / 2$ Guillard medium) concentrations were utilized in otherwise standard F/2 medium (Affan et al., 2007; Fakhry \& El-Maghraby, 2015). All cultures were grown for seven days per triplicate under the same standard conditions.

For chemical composition analyses, the same standard conditions and concentration of $\mathrm{F} / 2$ medium (control and treatments) was used in $100 \mathrm{~L}$ plastic containers with a volume of $40 \mathrm{~L}$. Microalgal biomass was harvested at the end of the exponential phase (day 5). Samples were centrifuged at $4,500 \mathrm{~g}$ at $4^{\circ} \mathrm{C}$ for 15 min; the supernatant was then removed, and the microalgal pellets were washed with sodium formate to remove the salt. Then the pellet was freeze-dried in a lyophilizer (Yamato Scientific Co., Japan) for $36 \mathrm{~h}$.

\section{Microalgal kinetic growth and chlorophyll- $a$ pro- duction}

Growth kinetics and biomass production were measured in order to determine cell density, development and crop quality. The stocking density of microalgae was 10,000 cells $\mathrm{mL}^{-1}$. Cultures were monitored daily, and duplicate aliquots were removed from each treatment. Cell concentration was measured using a Neubauer chamber (0.1 $\mathrm{mm}$ deep) and an Olympus optical microscope, and was calculated with the following equation (López-Elías et al., 1995):

Number of cells $=$ (The average number of cells in eight squares) $\times 10,000=\frac{\text { number of cells }}{\mathrm{mL}}$

Average growth rates were estimated using the formula (Courtois de Viçose et al., 2012):

$$
\mu=\frac{\ln \left(N_{1} / N_{0}\right)}{\left(\mathrm{t}_{1}-t_{0}\right)}
$$

where $\mathrm{N}_{1}$ : cell density in day $\mathrm{t}_{1}, \mathrm{~N}_{0}$ : cell density in time $\mathrm{t}_{0}$.

Chlorophyll- $a$ (Chl- $a$ ) was measured with the methodology of Tran et al. (2016) from day 0 to day 7. For the quantification of Chl- $a, 10 \mathrm{~mL}$ of the previously homogenized culture was centrifuged at $3,500 \mathrm{~g}$ at $4^{\circ} \mathrm{C}$ for $10 \mathrm{~min}$. The pellet was resuspended in $10 \mathrm{~mL}$ of $90 \%$ methanol, and the extract was stored in darkness at $4^{\circ} \mathrm{C}$ for $24 \mathrm{~h}$. The Chl- $a$ concentration was determined by using a spectrophotometer (Spectronic Model 20D+, Milton Roy) according to the equation:

$$
\text { Chl- } a=\left(\mathrm{mg} \mathrm{L}^{-1}\right)=13.43 \times \text { OD665 }
$$

where OD665 is the optical density (OD) measured at $665 \mathrm{~nm}$.

\section{The chemical composition of the microalgal biomass}

The chemical composition of the microalgae $N$. incerta in each treatment and the control was determined following the methodologies described by the AOAC (2005); ash content was determined by a muffle at $560^{\circ} \mathrm{C}$ for $4 \mathrm{~h}$, protein by the Kjeldahl method, lipid by the Soxhlet method, and carbohydrates were determined by difference of dry weight organic matter and the amount of protein and lipids.

\section{Statistical analysis}

Analyses were carried out in duplicate. The results of the cell concentration, chlorophyll, protein, lipids and carbohydrates analyses in the different treatments were reported as mean $\pm \mathrm{SD}$. Data were analyzed by one-way 
analysis of variance (ANOVA) and Tukey's multiple range test when necessary $(\alpha=5 \%)$. Statistical analyses were carried out using the program InfoStat (Di Rienzo et al., 2016).

\section{RESULTS}

\section{Concentration and growth rate}

The cellular concentration of Navicula incerta in the F/2 medium and the different treatments are presented in Figure 1. In both treatments, limiting in nitrogen or silicate, the stationary phase started on day 3 . All the treatments with nitrogen limitation presented a higher number of cells than treatment with silicate limitation. In the reduced nitrogen treatments, the highest cell concentration was found in the N/8 treatment $\left(2,391 \times 10^{5}\right.$ cells $\left.\mathrm{mL}^{-1}\right)$, while the lowest cell concentration was found in the N/16 treatment $\left(2,094 \times 10^{5}\right.$ cells $\left.\mathrm{mL}^{-1}\right)$. In the reduced silicate treatments, the highest cell concentration was in $\mathrm{Si} / 4\left(1,700 \times 10^{5}\right.$ cells $\left.\mathrm{mL}^{-1}\right)$, while the lowest was in $\mathrm{Si} / 16\left(1,633 \times 10^{5}\right.$ cells $\left.\mathrm{mL}^{-1}\right)$.

Figure 2 shows the growth rate in different treatments. It was observed that the exponential phase reached an average of 2.16 divisions per day. Throughout all the experiments, the media with reduced silicates showed the lowest number of cell divisions, in comparison with the reduced nitrogen and control media.

\section{Chlorophyll- $a$}

The chlorophyll- $a$ concentration was influenced by the treatments (Fig. 3). The highest concentration $(0.77 \mathrm{mg}$ $\mathrm{L}^{-1}$ ) of chlorophyll was found in the control treatment on day 4. Higher limitations of nitrogen (the N/16 treatment) and silicate (the $\mathrm{Si} / 8$ and $\mathrm{Si} / 16$ treatments) decreased the chlorophyll content.

\section{Proximal composition}

The effect of the limitation of nitrogen and silicates is depicted in Table 1. As can be observed, both treatments affect the ash, lipid, protein and carbohydrate content of $N$. incerta to different extents. There is no statistical difference $(P>0.05)$ in ash content between the control and the treatments, except for N/8 and N/16. Lipid concentration increases or decreases depending on the nutrient in limitation. In treatments $\mathrm{N}$ the concentration of lipids increases, while in treatments $\mathrm{Si}$ decreases. The lowest values of lipid content in nitrogen and silicate treatments were N/16 and Si/16, respectively. On the other hand, lipid content exhibited a statistical difference $(P>0.05)$, especially the N/8 and $\mathrm{Si} / 8$ treatments. In N/8, the lipid content increased to $27.09 \%$ (dry weight, DW), while in $\mathrm{Si} / 8$, it decreased to $16.08 \%$.

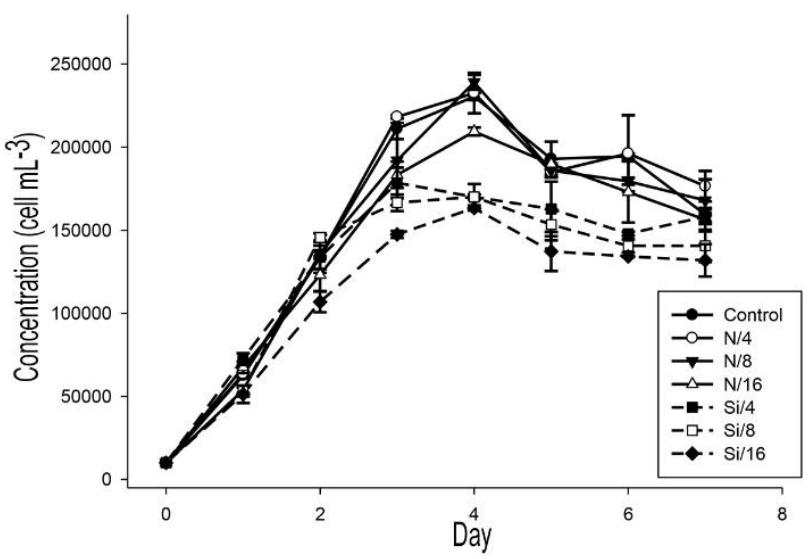

Figure 1. Effect of nitrogen and silicate limitation on the growth kinetics of Navicula incerta at different nitrogen $\left(\mathrm{N} / 4,0.44 \mathrm{~mol} \mathrm{~L}^{-1}\right.$; N/8, $0.22 \mathrm{~mol} \mathrm{~L}^{-1}$; and N/16, $0.11 \mathrm{~mol}$ $\left.\mathrm{L}^{-1}\right)$ or silicate $\left(\mathrm{Si} / 4,0.08 \mathrm{~mol} \mathrm{~L}{ }^{-1} ; \mathrm{Si} / 8,0.04 \mathrm{~mol} \mathrm{~L}^{-1}\right.$; and $\left.\mathrm{Si} / 16,0.02 \mathrm{~mol} \mathrm{~L}^{-1}\right)$ concentrations.

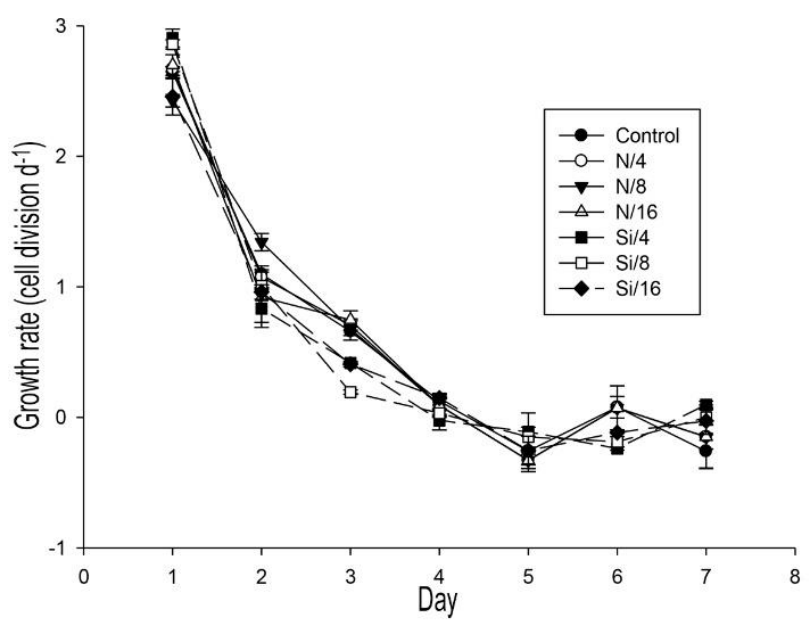

Figure 2. Effect of nitrogen or silicate limitation on the growth rate of Navicula incerta at different nitrogen (N/4, $0.44 \mathrm{~mol} \mathrm{~L}^{-1}$; N/8, $0.22 \mathrm{~mol} \mathrm{~L}^{-1}$; and N/16, $\left.0.11 \mathrm{~mol} \mathrm{~L}^{-1}\right)$ or silicate $\left(\mathrm{Si} / 4,0.08 \mathrm{~mol} \mathrm{~L}^{-1}\right.$; $\mathrm{Si} / 8,0.04 \mathrm{~mol} \mathrm{~L}^{-1}$; and $\mathrm{Si} / 16$, $0.02 \mathrm{~mol} \mathrm{~L}^{-1}$ ) concentrations.

\section{Protein content}

The protein content was influenced by the concentration of the nutrients in the medium. In the treatments with nitrogen limitation, the protein concentration decreased compared to the control, and the lowest value found in algae grown in the N/16 medium (14.85\%). In the reduced silicate treatments, the concentration decreased in all limiting media $(\mathrm{Si} / 4, \mathrm{Si} / 8$ and $\mathrm{Si} / 16)$ from 31 to $28 \%$ compared with the control medium $(35 \%)$.

\section{Carbohydrates content}

The carbohydrate concentration increased in the nitrogen and silicate treatments. The control medium showed the 


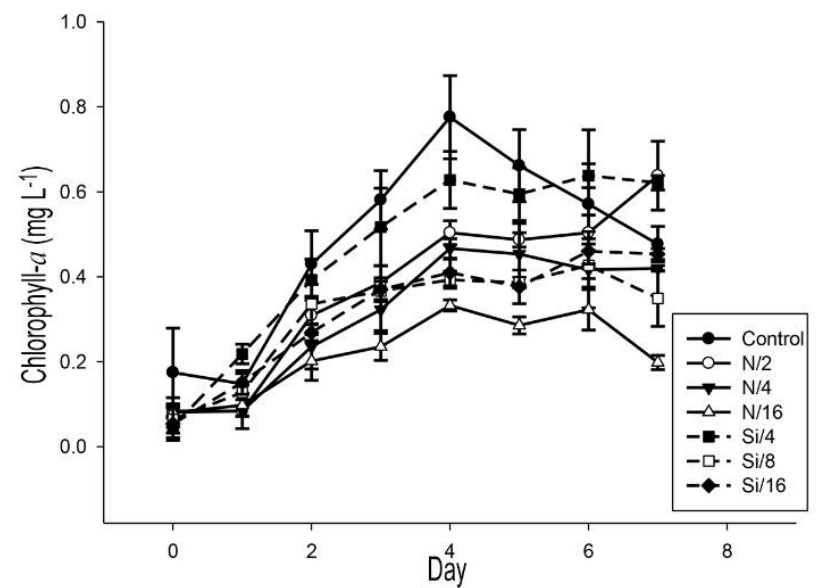

Figure 3. The concentration of chlorophyll- $a$ at different concentration of nitrates or silicate in $F / 2$ culture at different nitrogen $\left(\mathrm{N} / 4,0.44 \mathrm{~mol} \mathrm{~L}^{-1} ; \mathrm{N} / 8,0.22 \mathrm{~mol} \mathrm{~L}^{-1}\right.$; and $\left.\mathrm{N} / 160.11 \mathrm{~mol} \mathrm{~L}^{-1}\right)$ or silicate $\left(\mathrm{Si} / 4,0.08 \mathrm{~mol} \mathrm{~L}^{-1} ; \mathrm{Si} / 8\right.$, $0.04 \mathrm{~mol} \mathrm{~L}^{-1}$; and $\mathrm{Si} / 160.02 \mathrm{~mol} \mathrm{~L}^{-1}$ ) concentrations.

lowest content of $3.21 \%$, while the N/16 treatment showed the highest concentration at $23.31 \%$, followed by $\mathrm{Si} / 8$ condition $(19.9 \%)$.

\section{DISCUSSION}

\section{Concentration and growth rate}

In the present study, the different concentrations of nitrates and silicates in the culture medium affected biomass production, growth rate and nutritional quality. The low production of biomass and cell concentration are the product of the stress response to the low content of nutrients present in the medium (Fernández-Reiriz et al., 1989; Courtois de Viçose et al., 2012). This concentration in limited mediums, compared to those in other works (Courtois de Viçose et al., 2012; FimbresOlivarría et al., 2015; Jiang et al., 2015), may be due to the limitations of the nutrients ( $\mathrm{F}$ Guillard Medium uses urea at $4.26 \mathrm{~mol} \mathrm{~m}^{-3}$ as the $\mathrm{N}$ source in artificial brackish growth media) and the inoculum concentration employed for the experiment $(50,000,100,000$ or 250,000 cells $\left.\mathrm{mL}^{-1}\right)$. The concentration of cells in cultures with silicate limitation was lower compared to the control and the nitrate-limiting media. Courtois de Viçose et al. (2012), working with different cell concentrations of inoculum in diatoms $(50,000$, 100,000 and 250,000 cells $\mathrm{mL}^{-1}$ ), reported that the density of the inoculum affected growth rate and the chosen cell concentrations were different to those used in this work. Also, it has been reported that restricted cell division, different cell sizes and the synthesis of biological compounds comprise a survival strategy in algae for several stress factors, such as and nutrient limitation and $\mathrm{pH}$. Jiang et al. (2015) reported that silicate concentrations affect the carrying capacity (cells $\mathrm{m}^{-3}$ ) of the medium, but not the growth rate of the diatom.

\section{Chlorophyll content}

Chlorophyll is abundant in nature and plays a critical role in photosynthesis. This process converts light energy into chemical energy, using water and carbon dioxide to produce oxygen and carbohydrates (Rukminasari, 2013). Regarding the production of chlorophyll in this work, lower production was obtained in both treatments concerning the control. The conversion of solar energy into chemical energy at a lower rate is a survival strategy at low nutrient concentrations (Ding et al., 2017). Also, in the case of a low nitrate medium, the low concentration of chlorophyll was expected, since nitrogen is a key component of this compound, as well as of the proteins that contribute to the growth of microalgal cells (Kim et al., 2014; Song et al., 2016). Song et al. (2016) found that, at high concentrations of nitrogen $(\mathrm{N}: \mathrm{P}$ ratio, $16: 1)$, it is possible to observe higher values of chlorophyll $\left(2.3 \mathrm{mg} \mathrm{L}^{-1}\right)$ than at lower concentrations (N:P ratio, 1:1) in Dunaliella tertiolecta. This behavior is not affected by the source of nitrogen (urea or nitrates). The authors also mention that, with low nitrogen concentrations in the medium, the cells are unable to utilize intracellular nitrogen for the synthesis of cellular chlorophyll for subsequent cell production.

\section{Lipid content}

The concentration of lipids was influenced by media with low silicate and nitrate concentrations. In the case of nitrogen limitation, the concentration of lipids increased, with the N/8 treatment exhibiting the highest concentration $(27.09 \%)$, while the silicate limiting treatments decreased the lipid concentration, where the lowest concentration was found in the $\mathrm{Si} / 8$ treatment $(16.08 \%)$. It has been reported that silicate limitation leads to lipid accumulation in some diatoms, such as Chaetoceros gracilis and Nitzschia spp. (Taguchi et al., 1987; Jiang et al., 2015).

On the other hand, lipid concentrations have been reported at up to $22 \%$ for Navicula germanopolonica in salinity of 30 in the F Guillard medium (Leal et al., 2013 ) to $25.4 \%$ (Fimbres-Olivarría et al., 2015) for Navicula spp. in F Guillard medium. These differences are due to the different culture conditions and strain used. The authors attributed this behavior to the stress factors that were employed in these studies, such as salinity, light intensities and light wavelengths. Sánchez \& Núñez (2012) reported Navicula incerta with lipid content of $17.3 \%$. Shoba et al. (1989), wor- 
Table 1. Effect of nitrogen and silicate limitation on the proximate composition of Navicula incerta. At different nitrogen $\left(\mathrm{N} / 4,0.44 \mathrm{~mol} \mathrm{~L}^{-1} ; \mathrm{N} / 8,0.22 \mathrm{~mol} \mathrm{~L}^{-1}\right.$; and N/16, $\left.0.11 \mathrm{~mol} \mathrm{~L}^{-1}\right)$ or silicate $\left(\mathrm{Si} / 4,0.08 \mathrm{~mol} \mathrm{~L}^{-1} ; \mathrm{Si} / 8,0.04 \mathrm{~mol} \mathrm{~L}^{-1}\right.$; and Si/16, $0.02 \mathrm{~mol} \mathrm{~L}^{-1}$ ) concentrations in $\mathrm{F} / 2$ media expressed as percentage of dry weight (mean \pm standard deviation, $\mathrm{n}=6$ ). Different letters indicate significant differences $(P \leq 0.05),{ }^{\alpha} \mathrm{CHO}$ : carbohydrate.

\begin{tabular}{lcccc}
\hline Treatment & Ash $(\%)$ & Total lipid $(\%)$ & Total protein $(\%)$ & Total ${ }^{\circ} \mathrm{CHO}(\%)$ \\
\hline Control F/2 & $31.39 \pm 1.94^{\mathrm{ab}}$ & $21.38 \pm 0.23^{\mathrm{bc}}$ & $35.66 \pm 3.35^{\mathrm{a}}$ & $3.21 \pm 1.05^{\mathrm{f}}$ \\
Nitrogen limitation & & & & \\
Treatment N/4 & $32.90 \pm 1.64^{\mathrm{a}}$ & $21.87 \pm 1.94^{\mathrm{b}}$ & $29.52 \pm 0.68^{\mathrm{b}}$ & $6.76 \pm 1.23^{\mathrm{e}}$ \\
Treatment N/8 & $32.84 \pm 0.38^{\mathrm{a}}$ & $27.09 \pm 1.75^{\mathrm{a}}$ & $17.84 \pm 1.96^{\mathrm{c}}$ & $10.50 \pm 0.44^{\mathrm{d}}$ \\
Treatment N/16 & $33.53 \pm 0.47^{\mathrm{a}}$ & $21.15 \pm 1.80^{\mathrm{bc}}$ & $14.85 \pm 1.28^{\mathrm{c}}$ & $23.31 \pm 2.12^{\mathrm{a}}$ \\
Silicate limitation & & & & \\
Treatment Si/4 & $30.05 \pm 1.02^{\mathrm{b}}$ & $19.41 \pm 1.85^{\mathrm{bcd}}$ & $28.08 \pm 1.19^{\mathrm{b}}$ & $12.77 \pm 1.47^{\mathrm{cd}}$ \\
Treatment Si/8 & $26.97 \pm 0.70^{\mathrm{c}}$ & $16.08 \pm 1.37^{\mathrm{d}}$ & $31.38 \pm 1.58^{\mathrm{b}}$ & $19.04 \pm 1.57^{\mathrm{b}}$ \\
Treatment Si/16 & $26.55 \pm 0.73^{\mathrm{c}}$ & $16.12 \pm 9.69^{\mathrm{cd}}$ & $30.50 \pm 1.41^{\mathrm{b}}$ & $15.48 \pm 0.65^{\mathrm{c}}$ \\
\hline
\end{tabular}

king with Navicula saprophila, reported the same behavior for lipid and carbohydrate content under nitrogen limitation. This work contributes to the search for information on how nutrient levels in the medium affect biomass production and lipids in microalgae. Concerning lipid production, it was reported that these limitations affect the composition and production of polyunsaturated fatty acids and, in some cases, increased the amount of eicosapentaenoic acid (EPA) and docosahexaenoic acid (DHA) (Vitova et al., 2015; Mortensen \& Gislerød, 2016; Xia et al., 2016). The low lipid concentration in diatom cells under silicate limitation can be explained by metabolic acclimatization, which often results in alterations to their biochemical composition (Jiang et al., 2015).

\section{Protein content}

Protein concentration was affected by the different concentrations of nutrients in the culture medium. The decrease in protein content was expected in media with low concentrations of nitrates; however, the same case was observed in all the reduced silicate media. Comparing with other authors, protein content in the control medium $(35.36 \%)$ was higher than Leal et al. (2013) (Navicula germanopolonica, 21\% of protein), Sánchez \& Núñez (2012) (N. incerta, 30\% of protein) and Affan et al. (2007) (N. incerta, 7\% of protein). This difference could be due to the different species, growth conditions and growth medium. Nitrogen is an essential component of several compounds, such as proteins, DNA and chlorophyll; thus, the limitation of this nutrient affects the concentration of biomolecules in the organism, generating a stress condition (Song et al., 2016).

For this species, silicates are a component of their cell wall; thus, silicate limitation is another stressor factor for this organism. Jiang et al. (2015), working with Nitzschia perspicua, reported that a decrease in silicates in the medium affects the amount of protein and the lipid/protein ratio in diatoms. These alterations occur under stress conditions. However, for $N$. incerta, this behavior is observed to a higher degree in media with nitrogen limitation.

\section{Carbohydrate content}

A higher percentage of carbohydrates in both treatments were obtained compared to the control. The highest concentrations were present in the N/16 and $\mathrm{Si} / 8$ treatments (23.31 and $19.04 \%$, respectively), revealing that exposure to a medium with a nutrient limitation promotes the synthesis of carbohydrates. Despite the low production of biomass in treatments limited in silicates, this was compensated by the high production of carbohydrates, presenting an increase of six times in comparison with the control. FimbresOlivarría et al. (2015) reported percentages of carbohydrates at 3.09-4.013\% for Navicula spp., while Sánchez \& Núñez (2012) found a percentage of $10.1 \%$ for another species of Navicula. It has been reported that low concentrations of nutrients affect the cellular content of biological compounds. One of the methods utilized for their production is the limitation of these nutrients, because the limitations modify the Calvin cycle (Kim et al., 2014; De Farias-Silva et al., 2017), inducing a low production of proteins, and excess absorbed energy is then stored as carbohydrates or lipids. This process does result in a smaller amount of produced biomass (Rukminasari, 2013). Therefore, it is necessary to ascertain how nutrient limitation affects the lipid profile and the interactions of the remaining factors in order to obtain a higher number of compounds of interest.

\section{CONCLUSIONS}

The concentration of nitrate and silicate nutrients affects the growth rate and proximal biochemical 
composition of the microalgae Navicula incerta. In limited nitrate conditions, the production of lipids and carbohydrates is increased, while in silicate limitation, there is only an increase in the production of carbohydrates. The results of the present investigation suggest that $N$. incerta may be a good source for lipid and carbohydrate production in media with limited nitrogen and silicates, which would reduce the production cost while still maintaining cell density, increasing lipid and carbohydrates in the same time. However, it is necessary to know how the growth method affects the production of polyunsaturated fatty acids in $N$. incerta because of its importance for aquaculture and human nutrition.

\section{REFERENCES}

Affan, A., Karawita, R., Jeon, Y.J. \& Lee, J.B. 2007. Growth characteristics and antioxidant properties of the benthic diatom Navicula incerta (Bacillariophyceae) from Jeju Island, Korea. Journal of Phycology, 43: 823-832.

Association of Official Agricultural Chemists International (AOAC). 2005. Official methods of analysis of AOAC International. AOAC, Gaithersburg.

Courtois de Viçose, G., Porta, A., Viera, M.P., Fernández, P.H. \& Izquierdo, M.S. 2012. Effects of density on growth rates of four benthic diatoms and variations in biochemical composition associated with the growth phase. Journal of Applied Phycology, 24: 1427-1437. doi: 10.1007/s10811-012-9799-z

De Farias-Silva, C.E., Sforza, E. \& Bertucco, A. 2017. Stability of carbohydrate production in continuous microalgal cultivation under nitrogen limitation: effect of irradiation regime and intensity on Tetradesmus obliquus. Journal of Applied Phycology, 30(1): 261270. doi: 10.1007/s10811-017-1252-X

Ding, T., Yang, M., Zhang, J., Yang, B., Lin, K., Li, J. \& Gan, J. 2017. Toxicity, degradation and metabolic fate of ibuprofen on freshwater diatom Navicula sp. Journal of Hazardous Materials, 330: 127-134. doi: 10.1016/j.jhazmat.2017.02.004

Di Rienzo, J.A., Casanoves, F., Balzarini, M.G., Gonzalez, L., Tablada, M. \& Robledo, C.W. 2019. InfoStat versión 2016. Grupo ImfoStat, FCA, Universidad Nacional de Córdoba. [http://www. infostat.vom.ar]. Reviewed: January 12, 2019.

Fakhry, E.M. \& El-Maghraby, D.M. 2015. Lipid accumulation in response to nitrogen limitation and variation of temperature in Nannochloropsis salina. Botanical Studies, 56(6). doi: 10.1186/ s40529-0150085-7

Fernández-Reiriz, M.J., Pérez-Camacho, A., Ferreiro, M.J., Blanco, J., Planas, M., Campos, M.J. \& Labarta,
U. 1989. Biomass production nad variation in the biochemical profile (total protein, carbohydrates, RNA, lipids and fatty acids) of seven species of marine microalgae. Aquaculture, 83: 17-37.

Fimbres-Olivarría, D., López-Elías, J.A., MartínezCórdova, L.R., Carvajal-Millán, E., Enríquez-Ocaña, F., Valdez-Holguín, E. \& Miranda-Baeza, A. 2015. Growth and biochemical composition of Navicula sp. cultivated at two light intensities and three wavelengths. Israeli Journal of Aquaculture-Bamidgeh, 67: 1-7.

García-González, M., Cañavate, J.P., Anguis, V., Prieto, A. \& Manzano, J.C. 2005. Desarrollo y evaluación de la producción de betacaroteno por Dunaliella salina en la Bahía de Cádiz. Libro de Actas del IX Congreso Nacional de Acuicultura, Cádiz, pp. 347-352.

Guillard, R.L. \& Ryther, J.H. 1962. Studies on marine planktonic diatoms I. Cyclotella nana Husted and Detonula confervacea (Cleve) Gran. Canadian Journal of Microbiology, 8: 229-232.

Huang, X., Huang, Z., Wen, W. \& Yan, J. 2013. Effects of nitrogen supplementation of the culture medium on the growth, total lipid content and fatty acid profiles of three microalgae (Tetraselmis subcordiformis, Nannochloropsis oculata, and Pavlova viridis). Journal of Applied Phycology, 25: 129-137.

Jiang, Y., Nuñez, M., Starks, L.K. \& Quigg, A. 2015. Coupled effect of silicate and nickel on the growth and lipid production in the diatom Nitzschia perspicua. Journal of Applied Phycology, 27: 1137-1148. doi: 10.1007/s10811-014-0412-5

Kang, K.H., Qian, Z.J., Ryu, B.M. \& Kim, S.K. 2011. Characterization of growth and protein contents from microalgae Navicula incerta with the investigation of antioxidant activity of enzymatic hydrolysates. Food Science and Biotechnology, 20(1): 183-191. doi: 10.1007/s10068-011-0025-6

Kim, K.H., Choi, I.S., Kim, H.M., Wi, S.G. \& Bae, H.J. 2014. Bioethanol production from the nutrient stressinduced microalgae Chlorella vulgaris by enzymatic hydrolysis and immobilized yeast fermentation. Bioresource Technology, 153: 47-54.

Lari, Z., Moradi, N., Ahmadzadeh, H., Abrishamchi, P., Moheimani, N. \& Murry, M.A. 2016. Bioprocess engineering of microalgae to optimize lipid production through nutrient management. Journal of Applied Phycology, 28: 3235-3250.

Leal, S., Medina, M.A., Guerrero, M.A., Piña, P., Nieves, M. \& Curbelo, R. 2013. Concentración y composiciones orgánicas y proximales de dos especies de diatomeas bentónicas a diferentes salinidades. Universidad y Ciencia, 29(1): 45-52. 
López-Elías, J.A., Báez-Dueñas, M.D.C. \& Huerta-Aldáz, N. 1995. Manual de técnicas analíticas aplicada al cultivo de microalgas. CICTUS Publicaciones Académicas, Serie Ciencias Marinas, 5: 1-47.

Méndez-Martínez, Y., Pérez-Tamames, Y., Reyes-Pérez, J.J. \& Puente-Jiménez, V.D. 2018. Azolla sp., un alimento de alto valor nutricional para la acuicultura. Biotecnia, 20(1): 32-40.

Mooij, P.R., De Jongh, L.D., Van Loosdrecht, M.C.R. \& Kleerebezem, R. 2016. Influence of silicate on enrichment of highly productive microalgae from a mixed culture. Journal of Applied Phycology, 28: 1453-1457. doi: 10.1007/s10811-015-0678-2

Mortensen, L.M. \& Gislerød, H.R. 2016. The growth of Chlorella sorokiniana as influenced by $\mathrm{CO} 2$, light, and flue gas. Journal of Applied Phycology, 28: 813-820.

Pal, D., Khozin-Goldberg, I. \& Cohen, Z. 2011. The effect of light, salinity, and nitrogen availability on lipid production by Nannochloropsis sp. Applied Microbiology and Biotechnology, 90: 1429-1441. doi: 10.1007/ s00253-011-3170-1

Parashuramulu, S., Swain, P.S. \& Nagalakshmi, D. 2013. Protein fractionation and in vitro digestibility of Azolla in ruminants. Online Journal of Animal and Feed Research, 3: 129-132.

Perez-Garcia, O., Escalante, F.M.E., De-Bashan, L.E. \& Bashan, Y. 2011. Heterotrophic cultures of microalgae: metabolism and potential products. Water Resources, 45(1): 11-36.

Rema, P. \& Gouveia, L. 2005. Effect of various sources of carotenoids on survival and growth of goldfish (Carassius auratus) larvae and juveniles. Journal of Animal and Veterinary Advances, 4(7): 654-658.

Renaud, S.M., Parry, D.L. \& Thinh, L. 1994. Microalgae for use in tropical aquaculture I: Gross chemical and fatty acid composition of twelve species of microalgae from the northern territory, Australia. Journal of Applied Phycology, 6: 337-345.

Rukminasari, N. 2013. Effect of temperature and nutrient limitation on the growth and lipid content of three selected microalgae (Dunaliella tertiolecta, Nannochloropsis sp. and Scenedesmus sp.) for biodiesel production. International Journal of Marine Science, 3(17): 135-144. doi: 10.5376/ijms.2013.03.0017

Received: 14 March 2019; Accepted: 14 December 2019
Sánchez, M.P. \& Núñez, E. 2012. Photosynthetic and biochemical effects of cold storage on marine benthic diatoms of the Mexican Pacific coast. Journal of the World Aquaculture Society, 43(2): 249-258.

Song, D., Xi, B. \& Sun, J. 2016. Characterization of the growth, chlorophyll content, and lipid accumulation in a marine microalgae Dunaliella tertiolecta under different nitrogen to phosphorus ratios. Journal of the Ocean University of China, 15(1): 124-130. doi: 10.1007/s11802-016-2797-z

Shobha, S., Bagga, D. \& Sriharan, T.P. 1989. Environmental control of lipids and fatty acid production in the diatom Navicula saprophila. Applied Biochemistry and Biotechnology, 20-21: 281-291.

Spolaore, P., Joannis-Cassan, C. \& Duran, E. 2006. Review: commercial applications of microalgae. Journal of Bioscience and Bioengineering, 101: 87-97.

Taguchi, S., Hirata, J.A. \& Laws, E.A. 1987. Silicate deficiency and lipid synthesis of marine diatoms. Journal of Phycology, 23: 260-267.

Tran, N., Padula, P.M., Evenhuis, C.R., Commault, A.S., Ralph, P.J. \& Tamburic, B. 2016. Proteomic and biophysical analyses reveal a metabolic shift in nitrogen deprived Nannochloropsis oculata. Algal Research, 19: 1-11.

Tzovenis, I., De Pauw, N. \& Sorgeloos, P. 2003. Optimization of T-ISO biomass production rich in essential fatty acids: I. Effect of different light regimes on growth and biomass production. Aquaculture, 216: 203-222.

Vitova, M., Bišová, K., Kawano, S. \& Zachleder, V. 2015. Accumulation of energy reserves in algae: from cell cycles to biotechnological applications. Biotechnology Advances, 33: 1204-1218.

Wijffels, R.H. \& Barbosa, M.J. 2010. An outlook on microalgal biofuels. Science, 329: 796-799.

Xia, L., Song, S. \& Hu, C. 2016. Higher temperature enhances lipid accumulation in nitrogen-deprived Scenedesmus obtusus XJ-15. Journal of Applied Phycology, 28: 831-837.

Yaşar, D. \& Şevket, G. 2006. $\alpha$-tocopherol and fatty acids of Spirulina platensis biomass in glass panel bioreactor. Pakistan Journal of Biological Sciences, 9(15): 2901-2904. 